\title{
BRIEF CHRONOLOGY
}

1923

$1929-1938$

1939

I938-I94I

I94I-I943

I943-I946

$1946-1951$

$1952-1953$

I953-I955
Philip Glenn Whalen born in Portland, Oregon, on 20 October, only son of Glenn Henry and Phyllis Aminta (Bush) Whalen.

Attended public grade school and junior high school in The Dalles, Oregon.

Mother died.

Attended The Dalles High School, graduating May 194I. In

September 1941, moved with father to live in Portland.

Worked as office boy and laborer in airplane factory and shipyard.

Service with U.S. Army Air Corps as radio operator and mechanics instructor.

Attended Reed College, taking creative writing, graphic arts, language, and literature courses. First poems published in campus literary magazines. Met Lew Welch, Gary Snyder, and many more lifelong friends there; set type, carved linoleum blocks, and printed his first individual publication, Three Satires. The Calendar, a book of poems, written in I950-5I as thesis project required for B.A. Graduated I95I.

Odd jobs in Portland, San Francisco, Venice (CA).

Residence in San Francisco with Gary Snyder; long visits in Los Angeles with Leslie and Rosemary Thompson, friends from Reed College. Odd jobs.

Residence in San Francisco; summer work as lookout fireman in Mount Baker National Forest.

Fall and winter 1954, living with Ben Richard Anderson and his wife, Virginia Heath, in Newport, Oregon.

September 1955, residence in Berkeley. Met Jack Kerouac and Allen Ginsberg. Six Gallery reading on 7 October 1955, with Ginsberg, Lamantia, McClure, and Snyder; Kenneth Rexroth, master of ceremonies; first solo poetry reading later that year at the Poetry 
Center, under the direction of Ruth Witt-Diamant, at San Francisco State University.

I956 Reprise reading of the Six Gallery group, plus or minus various participants, at Berkeley Little Theater.

Poems published in "San Francisco Scene" issue of Evergreen Review.

Met Gregory Corso and gave him poems for Cambridge Review.

Living at Milvia Street, Berkeley; part-time work for University of

California at the Poultry Husbandry Laboratory.

1957-1958 First walking trip in Sierra Nevada, with Les Thompson, Robert Walker, and Max Woods.

In September, moved to Newport, Oregon, to work as circuit court bailiff for Judge Ben Richard Anderson of Lincoln County, Oregon.

Leroi Jones solicited book of poems. Like I Say completed and accepted for publication.

I959 Returned to San Francisco; participation in a number of public poetry readings (including benefit readings) with Ginsberg, McClure, Wieners, Spicer, Kyger, Duncan, and many other poets. October reading tour of colleges in New York and New England, with Michael McClure, arranged by Elsa Dorfman and Grove Press. As part of that, visited Charles Olson, Frank O’Hara, Joe LeSueur, and others.

Memoirs of an Interglacial Age completed and accepted for publication by Dave Haselwood's Auerhahn Press.

1960 Part-time work with U.S. Postal Service. Like I Say published in New York; Memoirs of an Interglacial Age published in San Francisco.

Second New England reading tour, arranged by the Paterson Society.

1961-1962 Wrote Brain Candy and Every Day.

Moved to Mill Valley to stay with Albert Saijo and family;

January 1962, Poets Foundation Award.

1963 Moved to San Francisco, the Beaver Street period. Wrote a novel, You Didn't Even Try.

University of British Columbia Poetry Conference (the "Vancouver Conference"), guest of Warren and Ellen Tallman.

Monday in the Evening published by Fernanda Pivano, Milan.

Recorded Like I Say and Memoirs of an Interglacial Age for Library of Congress Poetry Collection.

1964-1965 Coyote Books, an offshoot of Coyote's Journal, published Every Day.

Father died, September 1965.

Completed The Diamond Noodle, a prose text.

Filmed walking and reading for the NET series USA: Poetry.

Awarded a grant-in-aid by the National Academy of Arts and Letters. 
1966-1967 Highgrade (graphic works), edited and designed by Zoe Brown, published by Coyote Books.

Sailed to Japan for part-time teaching job in Kyoto.

Began a second novel, Imaginary Speeches for a Brazen Head, in August 1966, completed May 1967.

Intransit magazine (Bill Thomas) brought out the Philip Whalen issue.

You Didn't Even Try published by Coyote Books.

Returned to United States in November 1967, residence in Bolinas,

San Francisco, Stinson Beach, and Bolinas again.

1969-1971 Returned to Kyoto end of March 1969.

On Bear's Head (a collection of previously published works) pub-

lished by Harcourt, Brace \& World with Coyote Books.

Grant-in-aid from Committee on Poetry.

Severance Pay published by Four Seasons Foundation (Donald Allen).

"Many Happy Returns" commissioned by Tom Clark for his All

Stars anthology.

Second grant-in-aid from Committee on Poetry for Scenes of Life at the Capital, published by Grey Fox Press, June i97I.

Residence at Bolinas.

1972-1973 Moved to San Francisco Zen Center, February 1972.

Imaginary Speeches for a Brazen Head published by Black Sparrow.

Ordained unsui (Zen Buddhist monk), 3 February 1973.

1975-1976 Shuso (head monk) at Zenshinji, Zen Mountain Center, Tassajara, September-December 1975 .

Prolegomena to a Study of the Universe (prose texts from 1959-1960) published by Poltroon Press.

The Kindness of Strangers: Poems 1960-1974 published by the Four Seasons Foundation, Bolinas.

1972-1984 Lived as Zen monk and teacher in Zen Center locations in San Francisco and Tassajara.

Moved from San Francisco to Santa Fe, August 1984.

1975-1987 Visiting poet at Naropa University.

1978 Decompressions: Selected Poems published by Grey Fox Press, Bolinas.

1980 The Diamond Noodle published by Poltroon Press, Berkeley; designed by Alastair Johnston, illustrated by Frances Butler.

Enough Said: Poems 1974-1979 published by Grey Fox Press, Bolinas.

198I-1982 Resident teacher at South Ridge Zendo, Shogaku-an, San Francisco.

1984-1987 Resided in Santa Fe, New Mexico. 
Two Novels (Whalen's novels reprinted with an introduction by Paul Christensen) published by Zephyr Press, Somerville, Massachusetts, 1985.

Dharma transmission from Zentatsu Richard Baker, 23-30 July I987, at Crestone, Colorado.

1988-1990 Resided at Sanchez Street in San Francisco, then Issanji, Hartford Street Zen Center, serving as Godo (head of training).

I99I Mountain Seat Ceremony, making him the third abbot of Issanji, I 4 September.

1996 Retired as abbot of Issanji on Is August, remaining as teacher-in-residence.

Canoeing Up Cabarga Creek: Buddhist Poems, 1955-1986, introduction by Richard Baker, foreword by Allen Ginsberg, published by Parallax Press, Berkeley.

1999 Some of These Days, designed and printed by Clifford Burke, Desert Rose Press, San Jose, New Mexico.

Overtime: Selected Poems, with an introduction by Leslie Scalapino, edited by Michael Rothenberg, published by Penguin Books.

200I Goofbook: For Jack Kerouac, edited by Michael Rothenberg, published by Big Bridge Press, Pacifica, California.

2002 Perished, 26 June, Laguna Honda Hospice.

Philip Whalen Memorial Reading, 30 August, Presentation Theater, University of San Francisco.

Passing Over Ceremony, Green Gulch Farm, i September.

A number of posthumous publications of Whalen's work have appeared, most notably, The Collected Poems of Philip Whalen, edited by Michael Rothenberg (Middletown, CT: Wesleyan University Press, 2007). An invaluable resource, a monumental work, this volume presents the poems in chronological order of composition; it gives as well the original groupings at the time of first publication, in an appendix. The poems are indexed both by title and by first line. Though Philip began one preface, "I don't believe poets ought to write prefaces to their own work," he did. These are also collected and reprinted in an appendix running twenty pages. The book contains a very complete bibliography of Whalen's printed works, including broadsides.

Another posthumous book, a Festschrift, valuable for the photographs laboriously collected as well as the assembled tributes, is Continuous Flame: A Tribute to Philip Whalen, edited by Michael Rothenberg and Suzi Winson (New York: Fish Drum, 2005). 